Key Words:

In-Vitro Lung Solubility

Dose Conversion Factor

Metal Tritide

LANA.75

Retention:

Permanent

\title{
DETERMINATION OF IN-VITRO LUNG SOLUBILITY AND INTAKE-TO-DOSE CONVERSION FACTOR FOR TRITIATED LANTHANUM NICKEL ALUMINUM ALLOY
}

\author{
Authors: \\ Eduardo B. Farfán, Thomas R. LaBone, Gregory C. Staack, \\ Yung-Sung Cheng, Yue Zhou, and Thomas P. Varallo
}

November 11, 2011

Savannah River National Laboratory

Savannah River Nuclear Solutions

Aiken, SC 29808

Prepared for the U.S. Department of Energy Under

Contract Number DE-AC09-08SR22470

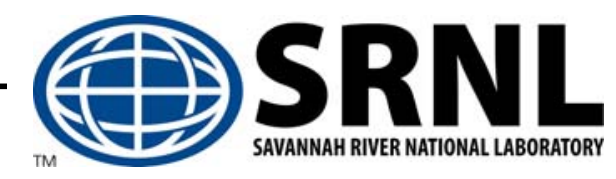




\section{DISCLAIMER}

This work was prepared under an agreement with and funded by the U.S. Government. Neither the U. S. Government or its employees, nor any of its contractors, subcontractors or their employees, makes any express or implied:

1. warranty or assumes any legal liability for the accuracy, completeness, or for the use or results of such use of any information, product, or process disclosed; or

2. representation that such use or results of such use would not infringe privately owned rights; or

3. endorsement or recommendation of any specifically identified commercial product, process, or service.

Any views and opinions of authors expressed in this work do not necessarily state or reflect those of the United States Government, or its contractors, or subcontractors.

Printed in the United States of America

Prepared for

U.S. Department of Energy 
Key Words:

In-Vitro Lung Solubility

Dose Conversion Factor

Metal Tritide

LANA.75

Retention:

Permanent

\title{
DETERMINATION OF IN-VITRO LUNG SOLUBILITY AND INTAKE-TO-DOSE CONVERSION FACTOR FOR TRITIATED LANTHANUM NICKEL ALUMINUM ALLOY
}

\author{
Authors: \\ Eduardo B. Farfán, Thomas R. LaBone, Gregory C. Staack, \\ Yung-Sung Cheng, Yue Zhou, and Thomas P. Varallo
}

November 11, 2011

Savannah River National Laboratory

Savannah River Nuclear Solutions

Savannah River Site

Aiken, SC 29808

Prepared for the U.S. Department of Energy Under

Contract Number DE-AC09-08SR22470 


\section{REVIEWS AND APPROVALS}

(The signatures are on file)

Eduardo B. Farfán, Co-author

Date

SRNL Environmental Science \& Biotechnology

Thomas R. LaBone, Co-author

Date

MJW Corporation Inc.

Gregory C. Staack, Co-author

Date

SRNL Hydrogen Processing Group

Yung-Sung Cheng, Co-author

Date

Lovelace Respiratory Research Institute

Yue Zhou, Co-author

Date

Lovelace Respiratory Research Institute

Thomas P. Varallo, Co-Author

Date

SRNL Hydrogen Processing Group

G. Timothy Jannik, Technical Reviewer

Date

SRNL Environmental Science \& Biotechnology

John J. Mayer, Level 3 Manager

Date

SRNL Environmental Science \& Biotechnology

Robert P. Addis, Level 3 Manager

Date

SRNL Defense Programs Technology 


\section{TABLE OF CONTENTS}

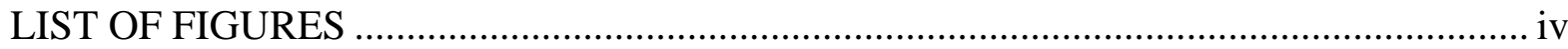

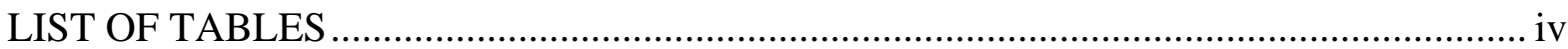

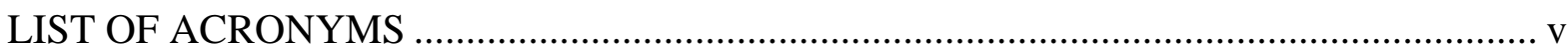

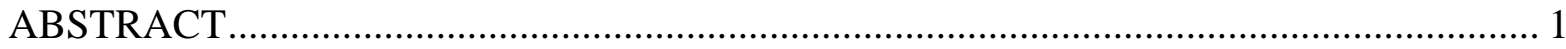

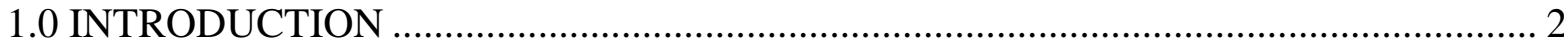

2.0 MATERIALS AND METHODS FOR DISSOLUTION STUDY ………...................... 2

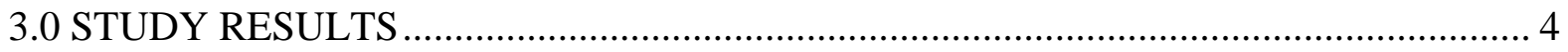

4.0 INTAKE-TO-DOSE CONVERSION FACTORS ……............................................... 7

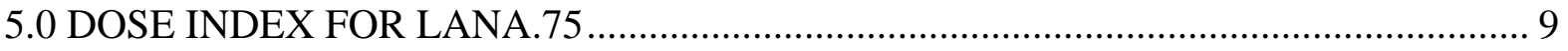

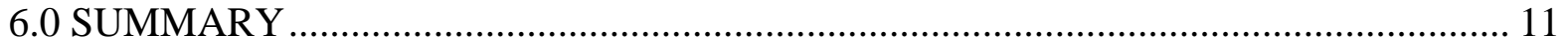

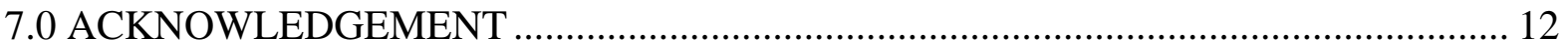

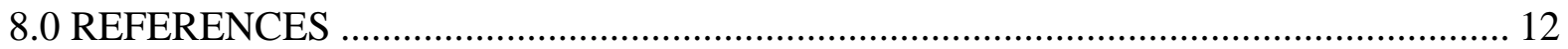

9.0 APPENDIX 


\section{LIST OF FIGURES}

Figure 1. Schematic diagram of the dissolution system. ........................................................... 3

Figure 2. Photomicrograph of test material. ....................................................................... 5

Figure 3. Particle size distribution of the test material. ............................................................ 5

Figure 4. Dissolution curves of LANA.75 (both $A(t)$ using all of the dissolution data and $A_{a}(t)$ using only the first 9 dissolution data) as compared to the dissolution curves of standard Type F, M, and S material. 6

Figure 5. Dose indices for LANA.75 compared to standard Type F, M, and S metal tritides.

\section{LIST OF TABLES}

Table 1. Summary of parameters for the LANA.75 particulate.

Table 2. Intake-to-dose conversion factors $\left(\mathrm{Sv} \mathrm{Bq}{ }^{-1}\right)$ for various tritiated materials. The numbers in the second column are the fraction of tritium that is absorbed from the GI tract and the numbers in the fourth column are the ratio of the DCF for the indicated

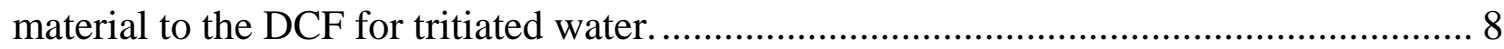

Table 3. DCFs as a function of aerosol AMAD and dissolution type. ................................ 9 


\section{LIST OF ACRONYMS}

$\begin{array}{ll}\text { AMAD } & \text { Activity median aerodynamic diameter } \\ \text { CED } & \text { Committed effective dose } \\ \text { CMD } & \text { Count median diameter } \\ \text { DCF } & \text { Intake-to-dose conversion factor } \\ \text { GI } & \text { Gastrointestinal } \\ \text { GSD } & \text { Geometric standard deviation } \\ \text { DOE } & \text { United States Department of Energy } \\ \text { HTO } & \text { Tritiated water } \\ \text { ICRP } & \text { International Commission on Radiological Protection } \\ \text { IMBA } & \text { Integrated Modules for Bioassay Analysis (software) } \\ \text { LANA.75 } & \text { LaNi } 4.25 \text { Al } \\ \text { L.75 } \\ \text { LRRI } & \text { Lovelace Respiratory Research Institute } \\ \text { NNSA } & \text { National Nuclear Security Administration } \\ \text { SRNL } & \text { Savannah River National Laboratory } \\ \text { SRNS } & \text { Savannah River Nuclear Solutions } \\ \text { SRS } & \text { Savannah River Site } \\ \text { SUF } & \text { Serum ultrafiltrate }\end{array}$


This Page Intentionally Left Blank 


\begin{abstract}
A sample of tritiated lanthanum nickel aluminum alloy ( $\mathrm{LaNi}_{4.25} \mathrm{Al}_{0.75}$ or LANA.75) similar to that used at the Savannah River Site Tritium Facilities was analyzed to estimate the particle size distribution of this metal tritide powder and the rate, at which this material dissolves in the human respiratory tract after it is inhaled. This information is used to calculate the committed effective dose received by a worker after inhaling the material. These doses, which were calculated using the same methodology given in the DOE Tritium Handbook, are presented as inhalation intake-to-dose conversion factors (DCF). The DCF for this metal tritide is less than the DCF for tritiated water and radiation worker bioassay programs designed for tritiated water are adequate to monitor for intakes of this material.
\end{abstract}




\subsection{INTRODUCTION}

Various metal tritides are encountered at the United States Department of Energy (DOE)'s Savannah River Site (SRS) Tritium Facilities. These metal tritides are essentially tritium in a particulate form, which can present radiological protection problems that are distinctly different than those of the more commonly encountered tritiated water (HTO). One such problem is that it is important to know the rate at which a tritide aerosol deposited in the respiratory tract releases tritium that is subsequently absorbed into the bloodstream. Tritium can be released from a tritide as a result of the metal matrix dissolving and releasing the tritium and by diffusion of the tritium from the intact metal matrix. For simplicity, in this discussion the release of tritium from a tritide by either mechanism is referred to as "dissolution."

The current understanding of some metal tritides is incomplete because the rate at which the material dissolves in the human respiratory tract is not known. DOE guidance is applied for the few metal tritides that have been studied. However, all the other metal tritides are currently grouped together and assumed to have "slow" dissolution behavior ${ }^{(1)}$. This assumption may lead to overly conservative estimates of the dose an individual would receive in the event of an intake, which makes it desirable to characterize the dissolution rate of metal tritides of interest such as lanthanum nickel aluminum (LaNiAl) alloy. This material is the most widely used at SRS. This work provides information on the dissolution rate of this material in the human respiratory tract, which is used to develop a technical basis for dose estimation associated with occupational intakes.

\subsection{MATERIALS AND METHODS FOR DISSOLUTION STUDY}

Tritiated metal ( $\mathrm{LaNi}_{4.25} \mathrm{Al}_{0.75}$ known as LANA.75) powder was provided by SRS. This powder was material from an actual process line. A total of $98.8 \mathrm{mg}$ powder in a sealed container was received. The powder sample was mixed and suspended in $0.5 \mathrm{~mL}$ of ethanol. Two drops of the suspension were placed on a glass slide for microscope count. Images taken from the optical microscope (Olympus, BX51, Japan) were analyzed for particle size by using Image Pro Plus software (Version 5.0, Media Cybernetics, Silver Spring, MD). From physical particle measurement and image analysis, the geometric or physical particle size distribution was determined in this study by calculating the projected area diameter (diameter of a spherical particle having the same area as the test particle) for each particle. The count median diameter (CMD) and geometric standard deviation (GSD) were obtained from the projected area diameter measurement by fitting the number distribution with a single modal lognormal distribution using the SigmaPlot software (v8.0, SPSS, Chicago, IL):

$$
f(d)=\frac{1}{\sqrt{2 \pi} d \ln \sigma_{g}} \exp \left[-\frac{\left(\ln d-\ln d_{o}\right)^{2}}{2\left(\ln \sigma_{g}\right)^{2}}\right]
$$

Eq. 1

or a bi-modal lognormal distribution: 


$$
f(d)=\frac{a}{\sqrt{2 \pi} d \ln \sigma_{g 1}} \exp \left[-\frac{\left(\ln d-\ln d_{o 1}\right)^{2}}{2\left(\ln \sigma_{g 1}\right)^{2}}\right]+\frac{1-a}{\sqrt{2 \pi} d \ln \sigma_{g 2}} \exp \left[-\frac{\left(\ln d-\ln d_{o 2}\right)^{2}}{2\left(\ln \sigma_{g 2}\right)^{2}}\right] \text { Eq. } 2
$$

where $d_{o}$ is the count median diameter (CMD) where $50 \%$ of particle counts exceed the value; and $\sigma_{\mathrm{g}}$ is the GSD of the distribution.

Serum ultrafiltrate (SUF) is an aqueous solution containing various salts ${ }^{(2)}$ and was used in a static dissolution system ${ }^{(3)}$ to determine the dissolution rates of the material. $1.18 \mathrm{mg}$ of test material was sandwiched between two 47-mm membrane filters (Tuffryn HT-200, 0.2- $\mu$ m pore size, Gelman Science, Ann Arbor, MI) and secured in a Teflon filter holder (Free-Flow Filter Holder 04-112, InTox Products, Albuquerque, NM). The filter holder was placed into a $500-\mathrm{mL}$ glass flask containing $100 \mathrm{~mL}$ of SUF incubated in a $37^{\circ} \mathrm{C}$ water bath.

The in-vitro dissolution apparatus was designed to measure the tritium in the gas phase (HT) and in solution. In most dissolution experiments, only the tritium dissolved in the solution is measured. However, the dissolved tritium in metal tritide could exist in HT or could exchange with protium in the water to form $\mathrm{HTO}^{(4)}$. Both types were accounted for in our in vitro experiment. Figure 1 shows a schematic diagram of the dissolution system, which consists of a water bath, dissolution flask, catalyst column, propylene glycol bubblers, and temperature controller.

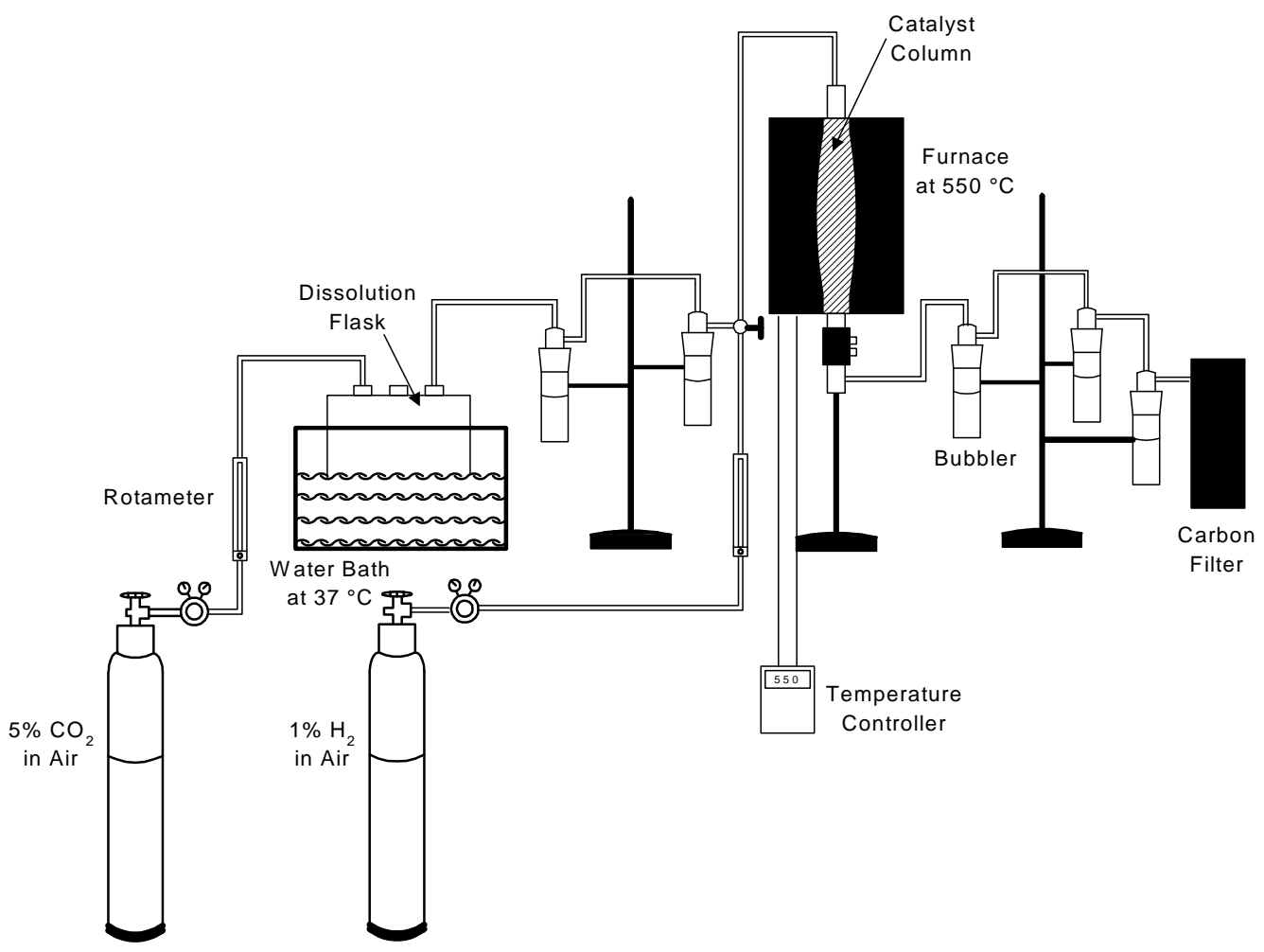

Figure 1. Schematic diagram of the dissolution system. 
The dissolution flask was kept sealed during the study. One hour before the solution was changed, air with 5\% $\mathrm{CO}_{2}$ (Argyle Supply Co., Albuquerque, NM) was passed through the flask, carrying the released HT and water vapor into two propylene glycol traps $(20 \mathrm{~mL})$ to remove the water and HTO vapors from the effluent. The HT then passed through a column packed with a precious metal sponge (GPT, Inc., Manalapan, NJ) maintained at $550^{\circ} \mathrm{C}$. The HT was oxidized by the catalyst into HTO, which passed through three more propylene glycol traps. The HTO collected in each bubbler and in the flask was analyzed in triplicate for ${ }^{3} \mathrm{H}$ using liquid scintillation counting methods (Packard Tri-Carb®, Model 2500TR, Packard Instrument Co., Meriden, CT). The flow rate through the system was $100 \mathrm{~mL} \mathrm{~min}{ }^{-1}$. A new solution then replaced the solution in the dissolution flask, and some of the HTO remained in the filter assembly. Following solution change, air containing 1\% hydrogen (Argyle Supply Co.) was used to purge the catalyst column for $2 \mathrm{~h}$ at a flow rate of around 1.0 $\mathrm{L} \mathrm{min}^{-1}$.

Solutions were changed at 1, 6, 24, 48, and 72 h, then twice weekly for 2.5 months. Before the change of the solution, the kettle and glycol traps were wiped twice with a paper towel. The dissolution rate in terms of percent activity per day was calculated by dividing the activity dissolved by the time and total activity. After the last change of solution, the remaining powders along with filters were dissolved in $40 \mathrm{~mL}$ of aqua regia (3 parts concentrated $\mathrm{HCl}$ and 1 part concentrated $\mathrm{HNO}_{3}$ ). The total activity of the sample was calculated from summing the activity collected in the dissolution flask, the bubblers, and the aqua regia. The percentage of ${ }^{3} \mathrm{H}$ dissolved in the SUF was plotted as a function of time. From this curve, the dissolution half-time in the SUF was determined. The analysis of the dissolution data was performed using nonlinear least-squares estimates ${ }^{(5,}$ ) procedure implemented in the Statistical Software R version 2.11.1 ${ }^{(7)}$.

\subsection{STUDY RESULTS}

A representative image of the test material is shown in Figure 2. The test material contains many large and small particles. Based on more than 300 particles counted, the projected area of each particle was measured. The projected area diameter, defined as the diameter of the circle that has the same projected can be calculated. The best fitted count distribution is shown in Figure 3. The test material showed a bi-modal distribution with the $\mathrm{CMD}_{1}$ and $\mathrm{CMD}_{2}$ of 0.9 and $7.4 \mu \mathrm{m}$ respectively. The GSDs of this distribution are 1.6 and 2.3 respectively. The value of $a$ in Eq. 2 is $0.41^{(8,9)}$. The activity median aerodynamic diameters (AMAD) shown in Table 1 were determined based on a shape factor of 1.5 and density of 8.0 $\mathrm{g} \mathrm{cm}^{-3(10)}$. 
SRNL-STI-2011-00587, REVISION 0

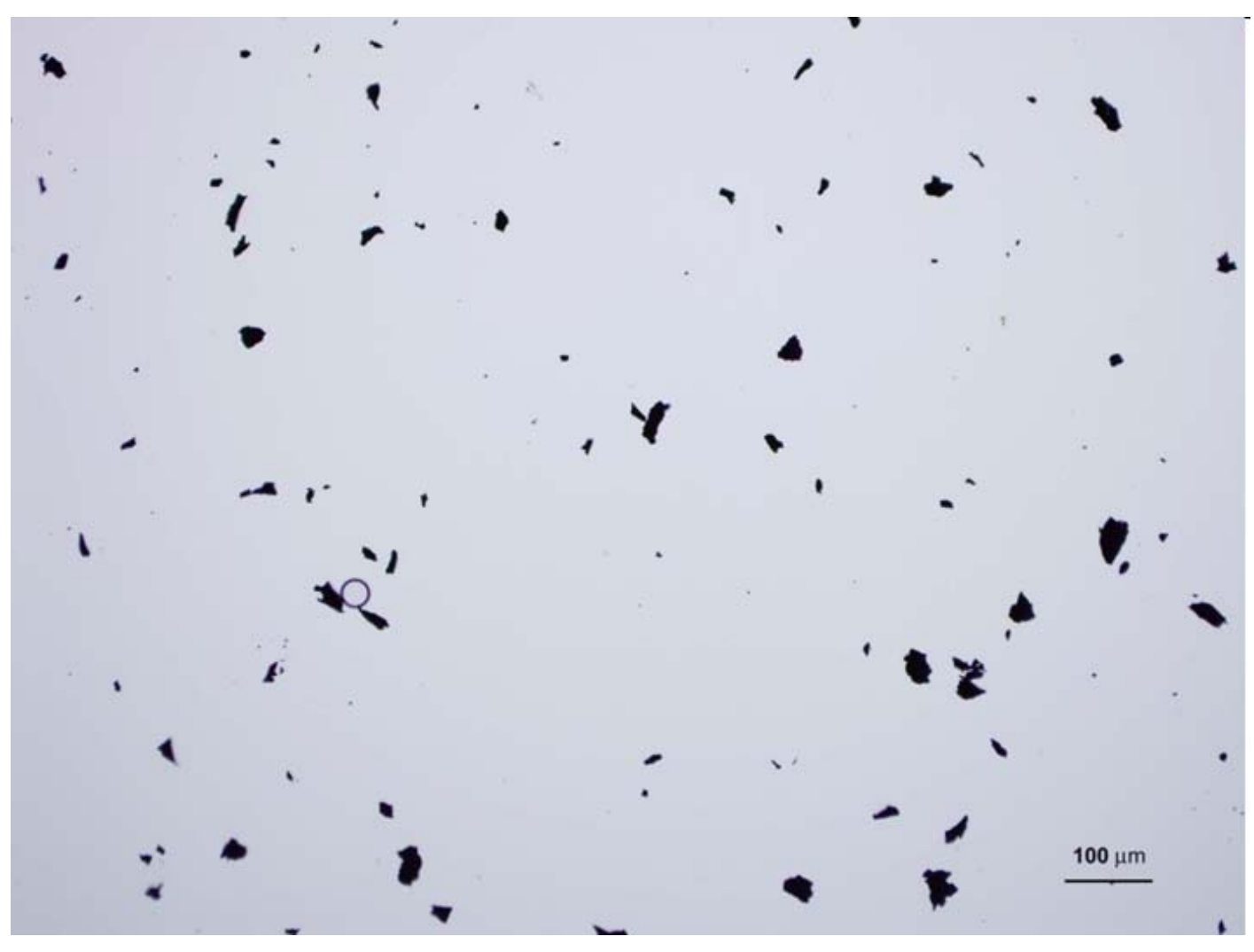

Figure 2. Photomicrograph of test material.

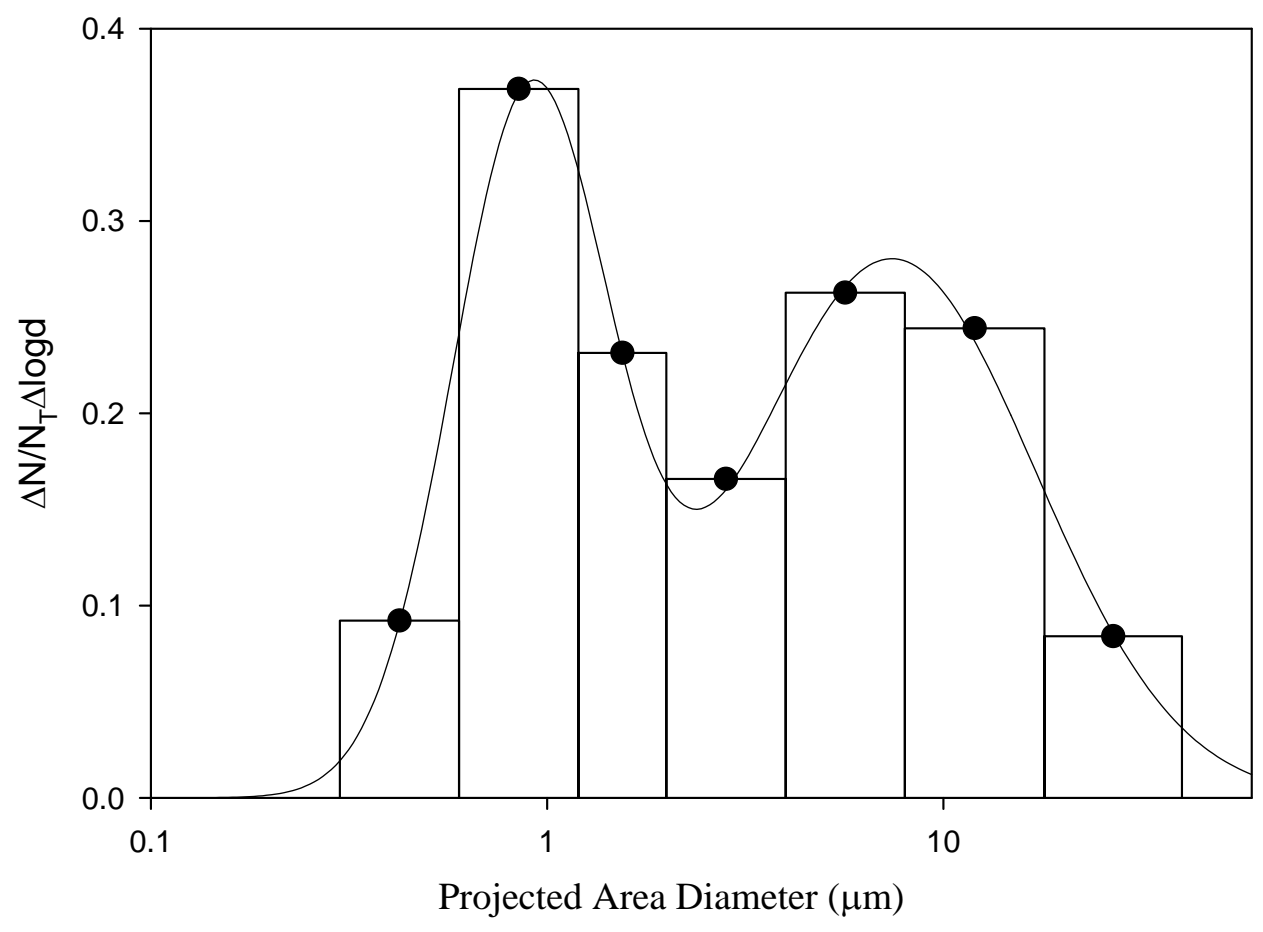

Figure 3. Particle size distribution of the test material. 
Table 1. Summary of parameters for the LANA.75 particulate.

\begin{tabular}{ccc}
\hline AMAD $(\mu)$ & GSD & Fraction \\
\hline 2.2 & 1.6 & 0.41 \\
17 & 2.3 & 0.59 \\
\hline
\end{tabular}

The fraction of activity remaining in the metal tritide particles as a function of time over 72 days was fitted to a two exponential function to give

$$
A(t)=0.995 \exp (-1.177 t)+0.005 \exp (-0.042 t) \quad \text { Eq. } 3
$$

where $A(t)$ is the fractional activity remaining at $t$ days. The dissolution data and the fitted curve are shown in Figure 4 . The results indicate that $>99 \%$ of the tritium was released in 10 days as a result of the LANA.75 matrix dissolving in the SUF and the tritium diffusing/offgassing from the matrix with this behavior is classified as dissolution Type $\mathrm{F}^{(11)}$.

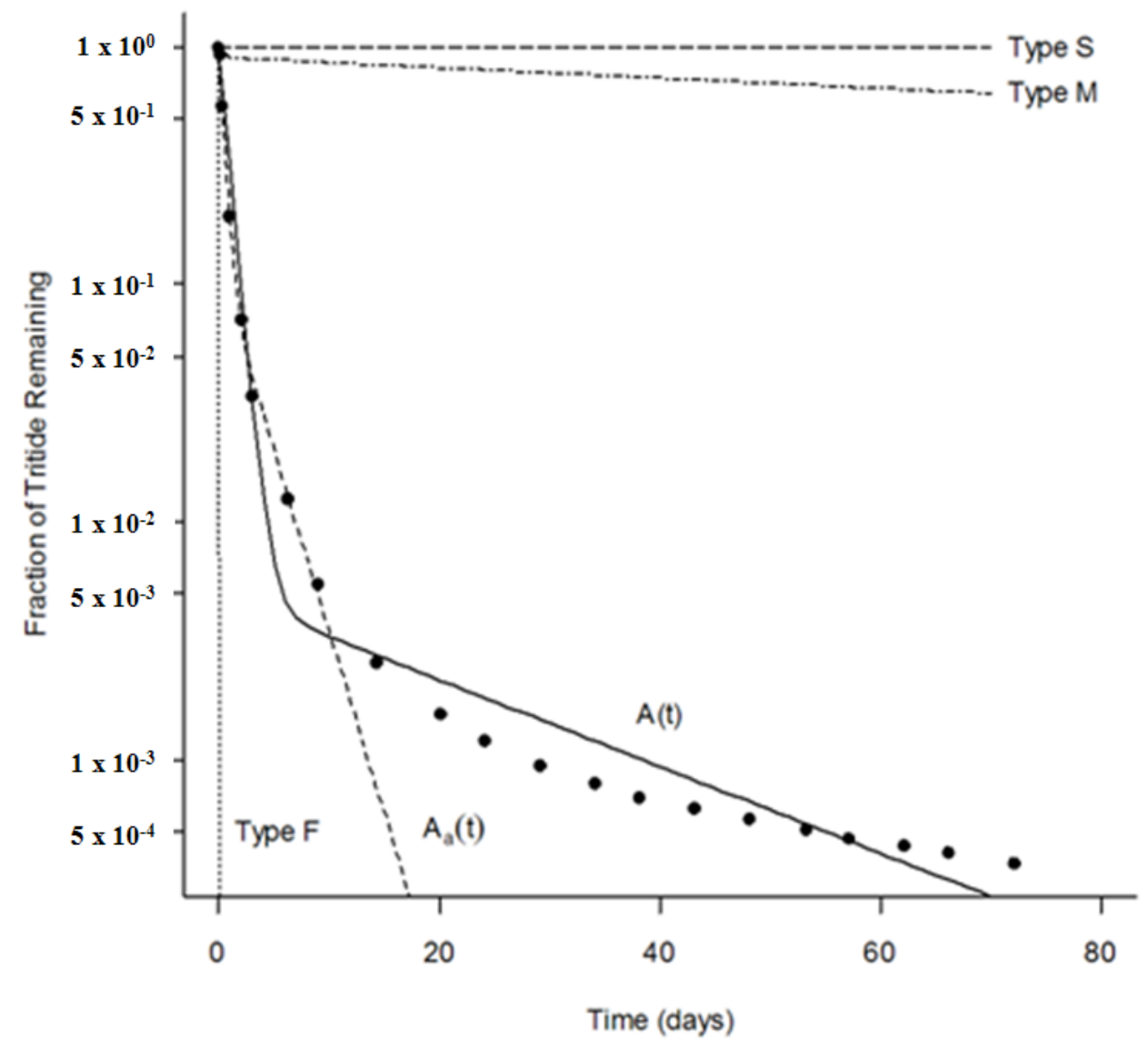

Figure 4. Dissolution curves of LANA.75 (both $A(t)$ using all of the dissolution data and $A_{a}(t)$ using only the first 9 dissolution data) as compared to the dissolution curves of standard Type F, M, and S material. 
There are at least two sources of error within the experiment. Tritium will incorporate itself into polymer filter holder and latter measurements may be artificially high due to tritium evolving from the holder. This amount may be very small because the remaining tritium in the material after dissolution study was observed to be about $1.2 \times 10^{6} \mathrm{~Bq}$. The dissolution rate of the final sample was $2.5 \times 10^{3} \mathrm{~Bq} \mathrm{~d}^{-1}$, which indicates that the most activity released into the SUF in last few days were still from the sample itself. This issue is discussed further from the perspective of dose calculations in Section 4.0.

Another error source may be from the reaction with the catalyst. There is a 20-day activity peak lag between the kettle and the last bubbler. The activity measured from the last 3 bubblers may be from the activity released 20 days ago. However, the maximum activity measured in the kettle was 1000 times higher than maximum activity in the bubbler. Thus, the error generated from the time lag is negligible. In addition, this error will also lead to a conservative estimate of the intake-to-dose conversion factor (DCF) for LANA.75.

\subsection{INTAKE-TO-DOSE CONVERSION FACTORS}

The function $\mathrm{A}(\mathrm{t})$ of the fitted curve (Eq. 1) gives the activity fraction of a unit quantity of LANA.75 remaining after being exposed to the simulated lung fluid for $t$ days. The parameters in Table 1 describe the size distribution of the particulate material. This materialspecific information can be "plugged" directly into the International Commission on Radiological Protection (ICRP) 66 Human Respiratory Tract Model ${ }^{(12)}$ in place of default 5 $\mu \mathrm{m}$ AMAD Type F, M, or S dissolution functions.

The LANA.75 dissolved rapidly, with less than $1 \%$ of the original activity remaining after 10 days. This is much faster than the dissolution rates observed for other metal tritides ${ }^{(13-15)}$ and as discussed previously raised a concern that the second term in $A(t)$ was the result of residual tritium in the apparatus used to perform the dissolution study rather than a characteristic of the LANA.75. The dosimetric significance of the second term in $A(t)$ was determined by fitting the first nine points of the dissolution data, which represents more than $99 \%$ of the tritium in the system, to give the following dissolution function $A_{a}(t)$ :

$$
A_{a}(t)=0.908 \exp (-2.265 t)+0.092 \exp (-0.3117 t)
$$

Eq. 4

Both dissolution curves are shown in Figure 4. The DCF for $5 \mu \mathrm{m}$ AMAD LANA.75 was calculated with $A(t)$ and $A_{a}(t)$. The DCF calculated with $A(t)$ is less than $1 \%$ higher than the DCF calculated with $A_{a}(t)$, which means that the second term of $A(t)$ is not of practical significant and that questions concerning its origins do not need to be resolved prior to using it to calculate DCF for LANA.75. A(t) also leads to a conservative DCF estimate.

The size distribution of the LANA.75 particulate was found by LRRI to be adequately described by a bimodal lognormal distribution. The activity median aerodynamic diameters (AMAD) and geometric standard deviations $\left(\sigma_{g}\right)$ reported for both lognormal components are given in Table 1 . The density of the LaNiAl was assumed to be $8 \mathrm{~g} \mathrm{~cm}^{-3}$. 
The DCF for the bimodal LANA.75 particulate was determined by calculating the DCF for the $0.9 \mu \mathrm{m}$ CMD component and the $7.4 \mu \mathrm{m}$ component separately and then adding them together in the proportions indicated in the last column of Table 1 . The DCFs ${ }^{1,2}$ calculated with IMBA Professional Plus V4.1.18 ${ }^{(16,17)}$ for various types of tritiated materials are given in Table 2 and the DCFs as a function of the following aerosol AMADs and dissolution are presented in Table 3:

- Type $\mathrm{S}-5 \mu \mathrm{m}$ AMAD aerosol $\left(\sigma_{\mathrm{g}}=2.5, \rho=3 \mathrm{~g} \mathrm{~cm}^{-3}\right)$ with standard Type $\mathrm{S}$ dissolution function.

- Type M - $5 \mu \mathrm{m}$ AMAD aerosol $\left(\sigma_{\mathrm{g}}=2.5, \rho=3 \mathrm{~g} \mathrm{~cm}^{-3}\right)$ with standard Type M dissolution function.

- Type F - $5 \mu \mathrm{m}$ AMAD aerosol $\left(\sigma_{\mathrm{g}}=2.5, \rho=3 \mathrm{~g} \mathrm{~cm}^{-3}\right)$ with standard Type F dissolution function.

- LANA.75 5.0 - $5 \mu \mathrm{m}$ AMAD aerosol $\left(\sigma_{\mathrm{g}}=2.5, \rho=3 \mathrm{~g} \mathrm{~cm}^{-3}\right)$ with dissolution function $A(t)$.

- LANA.75 2.2 - 2.2 $\mu$ m AMAD aerosol $\left(\sigma_{\mathrm{g}}=1.6, \rho=8 \mathrm{~g} \mathrm{~cm}^{-3}\right)$ with LRRI dissolution function $A(t)$.

- LANA.75 17 - $17 \mu$ m AMAD aerosol $\left(\sigma_{\mathrm{g}}=2.3, \rho=8 \mathrm{~g} \mathrm{~cm}^{-3}\right)$ with LRRI dissolution function $A(t)$.

- $\quad$ LANA - 41\% LANA.75 2.2 plus 59\% LANA.75 17.

- HTO - tritiated water.

Table 2. Intake-to-dose conversion factors $\left(\mathrm{Sv} \mathrm{Bq}^{-1}\right)$ for various tritiated materials. The numbers in the second column are the fraction of tritium that is absorbed from the GI tract and the numbers in the fourth column are the ratio of the DCF for the indicated material to the DCF for tritiated water.

\begin{tabular}{lccc}
\hline Metal Tritide Type & f1 & DCF & Ratio \\
\hline Type S & 0.01 & $1.30 \times 10^{-10}$ & 7.10 \\
Type M & 0.1 & $2.81 \times 10^{-11}$ & 1.54 \\
Type F & 1 & $9.03 \times 10^{-12}$ & 0.49 \\
LANA.75 5.0 & 0.9 & $9.40 \times 10^{-12}$ & 0.51 \\
LANA.75 2.2 & 1 & $1.05 \times 10^{-11}$ & 0.57 \\
LANA.75 17 & 1 & $7.12 \times 10^{-12}$ & 0.39 \\
LANA & 1 & $8.49 \times 10^{-12}$ & 0.46 \\
HTO & ----- & $1.83 \times 10^{-11}$ & 1.00 \\
\hline
\end{tabular}

\footnotetext{
${ }^{1}$ The DCF presented in this paper do not account for self-absorption of the radiation emitted from the tritium particle. This results in conservative values of the DCF.

${ }^{2}$ DCF calculated with IMBA are essentially the same as those calculated in DOE-HDBK-1129-2008 ${ }^{(1)}$.
} 
Table 3. DCFs as a function of aerosol AMAD and dissolution type $\left(\mathrm{Sv} \mathrm{Bq}^{-1}\right)$.

\begin{tabular}{rccc}
\hline AMAD & \multicolumn{3}{c}{ Dissolution Type } \\
\cline { 2 - 4 }$(\mu)$ & $\mathrm{F}$ & $\mathrm{M}$ & $\mathrm{S}$ \\
\hline 0.1 & $7.32 \times 10^{-12}$ & $1.04 \times 10^{-10}$ & $6.54 \times 10^{-10}$ \\
0.2 & $4.98 \times 10^{-12}$ & $6.72 \times 10^{-11}$ & $4.20 \times 10^{-10}$ \\
0.5 & $4.81 \times 10^{-12}$ & $4.57 \times 10^{-11}$ & $2.76 \times 10^{-10}$ \\
1 & $6.47 \times 10^{-12}$ & $4.27 \times 10^{-11}$ & $2.45 \times 10^{-10}$ \\
2 & $8.35 \times 10^{-12}$ & $4.02 \times 10^{-11}$ & $2.16 \times 10^{-10}$ \\
5 & $9.03 \times 10^{-12}$ & $2.81 \times 10^{-11}$ & $1.30 \times 10^{-10}$ \\
10 & $8.02 \times 10^{-12}$ & $1.72 \times 10^{-11}$ & $6.29 \times 10^{-11}$ \\
\hline
\end{tabular}

The DCF calculate for LANA.75 using dissolution function $A(t)$ is $7.91 \times 10^{-12} \mathrm{~Sv} \mathrm{~Bq}^{-1}$. The DCF calculated for LANA.75 using a default AMAD of $5 \mu \mathrm{m}$ and a default density of $3 \mathrm{~g}$ $\mathrm{cm}^{-1}$ is $9.4 \times 10^{-12} \mathrm{~Sv} \mathrm{~Bq}^{-1}$ ( 19\% higher). For routine applications in occupational radiation protection we recommend that a DCF of $9.4 \times 10^{-12} \mathrm{~Sv} \mathrm{~Bq}^{-1}$ be used for LANA.75 The DCF for LANA.75 is approximately one half of the DCF for HTO because only part of the inhaled LANA.75 is transferred to the systemic organs and tissues (because it is a particulate aerosol) whereas all inhaled HTO is transferred (because it is a vapor).

\subsection{DOSE INDEX FOR LANA.75}

The DCF for a radioactive material gives the dose per unit intake. In practice, intakes of tritiated radioactive materials like LANA.75 are usually not measured directly but are instead inferred from urine bioassay measurements. For this reason it is useful to examine the dose implied by a unit quantity of tritium in the urine rather than a unit intake. Further, it is often useful to express this dose per unit activity in the urine relative to the dose per unit activity in the urine following an intake of HTO. This dose index gives an idea of the magnitude of the error associated with the incorrect assumption that all tritium in the urine came from intakes of HTO when in reality the intake was a metal tritide.

For example, assume that an acute inhalation intake of $5 \mu \mathrm{m}$ AMAD Type F metal tritide produces a urine bioassay result $M_{f}(t)$ at $t$ days after the intake. Given the appropriate intake retention fraction (IRF) $m_{f}(t)$ and $D C F_{f}$, the committed effective dose (CED) $H_{f}(t)$ is

$$
\begin{array}{ll}
H_{f}(t)=D C F_{f}\left(\frac{M(t)}{m_{f}(t)}\right) & \text { Eq. } 5
\end{array}
$$

The IRFs used in this report were calculated with Integrated Modules for Bioassay Analysis (IMBA) software using a custom HTO urine bioassay model ${ }^{(12)}$. The ratio of $\mathrm{H}_{\mathrm{f}}(\mathrm{t})$ to the dose $\mathrm{H}_{\mathrm{hto}}(\mathrm{t})$ that would be calculated assuming the tritium in the urine resulted from an intake of tritiated water is 


$$
R_{f}(t)=\frac{D C F_{f}\left(\frac{M(t)}{m_{f}(t)}\right)}{D C F_{h t o}\left(\frac{M(t)}{m_{h t o}(t)}\right)}=\frac{D C F_{f}\left[m_{h t o}(t)\right]}{D C F_{h t o}\left[m_{f}(t)\right]}
$$

Eq. 6

The ratio $R_{f}(t)$ is the dose index for a Type $F$ metal tritide. A dose index in excess of 1 indicates that the dose from an intake of the metal tritide will be underestimated if one assumes that the intake was HTO. Dose indices for LANA.75 and standard Type F, M, and S metal tritides are shown in Figure 5. The plots show that the dose resulting from intakes of Type F metal tritide and LANA.75 are not significantly underestimated if one assumes that the inhaled material was tritiated water. In addition, the difference between the dose index of LANA.75 calculated with $A(t)$ and the dose index of LANA.75 calculated with $A_{a}(t)$ is not of practical significance. This provides further justification for using the DCF of $9.4 \times 10^{-12} \mathrm{~Sv}$ $\mathrm{Bq}^{-1}$ for LANA.75. In contrast, the plots show that if the intake were Type $\mathrm{M}$ or Type $\mathrm{S}$ metal tritide the dose will be significantly (even grossly) underestimated if one assumes that the intake was HTO. The practical significance of this is that the occupational internal dosimetrist can assume that all tritium in a urine bioassay came from intakes of HTO if only HTO or Type F materials could have been inhaled. This greatly simplifies design of monitoring programs and the interpretation of bioassay data. A brief explanation of DCFs is presented in the Appendix of this report. 


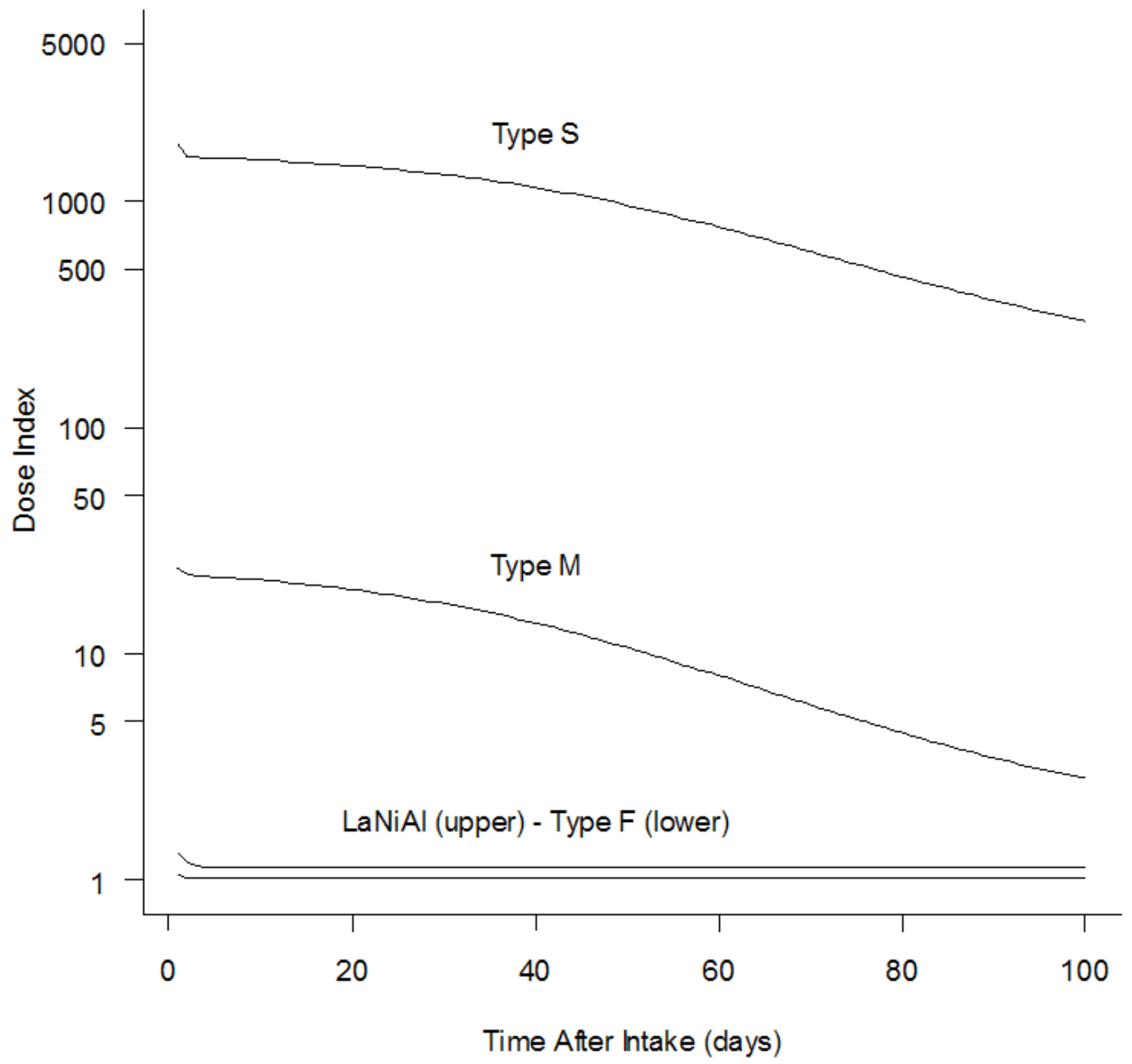

Figure 5. Dose indices for LANA.75 compared to standard Type F, M, and S metal tritides.

\subsection{SUMMARY}

The analysis of a tritiated LANA.75 sample provided data that was used to calculate a DCF of $9.4 \times 10^{-12} \mathrm{~Sv} \mathrm{~Bq}^{-1}$ for this material. Perhaps of greater practical significance is that the data made it feasible to demonstrate that tritium in a urine bioassay can be interpreted as if it had resulted from intakes of pure HTO if the worker was potentially exposed to any mixture of HTO and LANA.75. 
SRNL-STI-2011-00587, REVISION 0

\subsection{ACKNOWLEDGEMENT}

The authors of this report would like to thank the National Nuclear Security Administration (NNSA) Nuclear Safety Research and Development Working Group for its support of this project. The authors would also like to thank the many people in the SRS Tritium Facilities and SRNL who worked to safely prepare and deliver the tritided LANA.75 sample to LRRI.

\subsection{REFERENCES}

1. DOE Handbook. Tritium handling and safe storage. Department of Energy Handbook: DOE-HDBK-1129-2008 (2008).

2. Cheng, Y. S., Dahl, A. R., and Jow, H. N. Dissolution of metal tritide in a simulated body fluid. Health Phys., 73:633-638 (1997).

3. Kanapilly, G.M. Alveolar microenvironment and its relationship to the retention and transport into blood of aerosols deposited in the alveoli. Health Phys. 32:89-100 (1979).

4. Miller, J.M.; Bokwa, S.R. Leaching behavior of high specific activity tritium tritide. AECL-8870. Chalk River Nuclear Laboratories. Chalk River, Canada (1985).

5. Bates, D. M. and Watts, D. G. Nonlinear regression analysis and its applications. Wiley (1988).

6. Bates, D. M. and Chambers, J. M. Nonlinear models. Chapter 10 of Statistical Models in Seds J. M. Chambers and T. J. Hastie, Wadsworth \& Brooks/Cole (1992).

7. R Development Core Team. R: A language and environment for statistical computing. $\mathrm{R}$ Foundation for Statistical Computing, Vienna, Austria. ISBN 3-900051-07-0 (2010).

8. Cheng, Y.S., Holmes, T.D., Gao, J. Guilmette, R.A., Li, S., and Surakitbanharn, Y., and Rowlings, C. Characterization of nasal spray pumps and deposition pattern in a replica of the human nasal airway. J. Aerosol Medicine 14:267-280 (2001).

9. Cheng, Y.S. Zhou, Y., Gentile, C.A., and Skinner,C.H. Characterization of carbon tritide particles in a Tokamak fusion reactor. Fusion Sci. Technol. 41:867-87 (2002).

10. Cheng, Y. S., R. A. Guilmette, Y. Zhou, J. Gao, T. LaBone, J. J. Whicker and M. D. Hoover: Characterization of Plutonium Aerosol Collected During an Accident. Health Phys. 87(6): 596-605, 2004.

11. International Commission on Radiological Protection. Guide for the Practical Application of the ICRP Human Respiratory Tract Model. Annal of the ICRP 32 (1-2) (2002).

12. International Commission on Radiological Protection. Human respiratory tract model for radiological protection. Publication 66, Annal of ICRP, Vol. 24 (1994).

13. Cheng, Y.S., Zhou, Y., Krenik, T.D., Gao, G. Characterization of carbon tritide particles. Lovelace Respiratory Research Institute internal report. (2001).

14. Zhou, Y., Cheng, Y.S. Dosimetry of metal tritide particles as evaluated by the ICRP 66 model and a biokinetic model from laboratory rats. Health Phys 86:155-160 (2004).

15. Cheng, Y.S., Zhou, Y., Wang, Y.S., Inkret, W.C., Wermer, J.R. Dose estimate of inhaled hafnium tritide using the ICRP 66 lung model. Health Phys 82:817- 824 (2002).

16. IMBA Professional Plus, UK Health Protection Agency. Available on http://www.imbaprofessional.com/ (assessed on 15 August 2011)

17. Guidance on the Use of IMBA Software for DOE Safety Applications, US Department of Energy Document: DOE-HS-0002 (2006). 


\subsection{APPENDIX}

The DCFs are expressed as the dose per unit "intake", where the intake is what goes into the respiratory tract. Therefore, the DCF takes into account material that is removed from the body after it is inhaled. The DCF is never expressed as the dose per unit deposition, where deposition is the part of the intake that remains in the body. Some of the metal tritide deposited in the respiratory tract is translocated to the gastrointestinal tract. For Type F metal tritide all of the tritium in this "ingested" metal tritide is assumed to be absorbed into the bloodstream. This is not true for Type M and S metal tritides; thus, the calculation shown on the figure below is (approximately) true only for Type F tritides.

DCF for HTO vapor $(100 \%$ of intake is deposited in systemic organs and tissues)

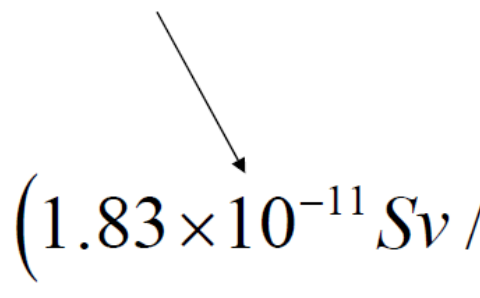

\section{Inhaled}

$1.0000 \mathrm{~Bq}$ tritide
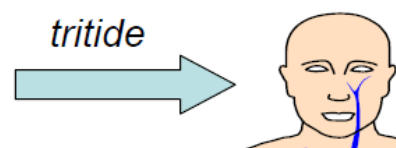

$0.1804 \mathrm{~Bq}$
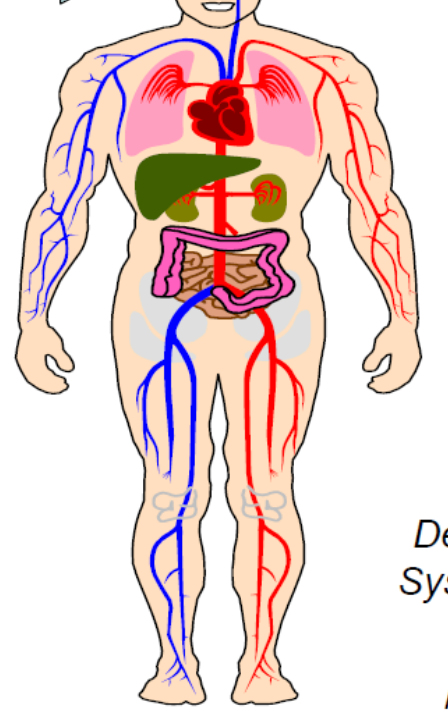

\section{Deposited in Systemic Body \\ $0.4811 \mathrm{~Bq}$}

Fraction of inhaled particulate that Is deposited in systemic organs and tissues

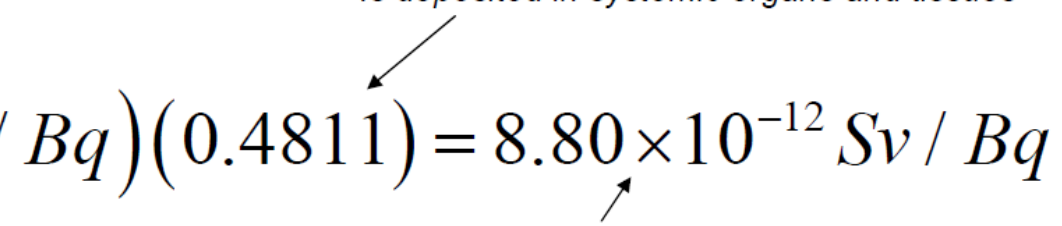

Cleared from respiratory tract, out of body quickly (gives small dose)

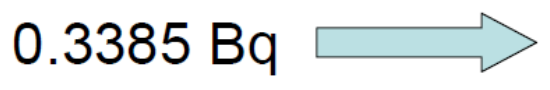

DCF for $5 \mu \mathrm{m}$ AMAD Type $F$ tritide aerosol 


\section{DETERMINATION OF IN-VITRO LUNG SOLUBILITY AND INTAKE-TO-DOSE CONVERSION FACTOR FOR TRITIATED LANTHANUM NICKEL ALUMINUM ALLOY}

\section{DISTRIBUTION}

J. E. Marra

A.M. Murray

J. J. Mayer

R.P. Addis

T. P. Varallo

G. C. Staack

G. T. Jannik

E. B. Farfán

Y. S. Cheng

Y. Zhou

T.R. LaBone

D.P. Potocik

T.B. Edwards

D.K. Utley

T.D. Harrington

L.M. Schifer

J.R. Dollar

W.M. Findley

J.D. Newell

S.C. Cannon

SRNL Records

EDG Records

MJW Corp.

LRRI
SRNL 773-A
SRNL 773-A
SRNL 773-42A
SRNL 773-A
SRNL 999-2W
SRNL 999-2W
SRNL 773-42A
SRNL 773-42A

Lovelace Respiratory Research Institute

Lovelace Respiratory Research Institute

MJW Corp.

SRNS 264-1H

SRNS 264-1H

SRNS 235-H

SRNS 235-H

SRNS 235-H

SRNS 235-H

SRNS 735-4B

NNSA 246-H

NNSA 246-H

SRNL 773-52A

SRNL 773-42A 